\title{
NUOLATINĖS PRIVALOMOSIOS PRADINĖS KARO TARNYBOS KARIŲ MOTYVACIJOS ANALIZE NACIONALINIO SAUGUMO KONTEKSTE
}

\author{
Srž. sp. Gerda Baltutytė \\ Dr. Jono Basanavičiaus karo medicinos tarnyba
}

\begin{abstract}
Anotacija. Straipsnyje analizuojama Lietuvos kariuomenès kariu tarnybos motyvacija remiantis ju nuomone. Suformuluojama kariu tarnybos motyvacijos teorine prieiga, akcentuojama vertybiu reikšmé motyvacijos procese, išskiriami lūkesčiai, remiantis V. H. Vroom lūkesčiu teorija, kurie salygoja nuolatinę privalomaja karo tarnyba atliekančiu kariu tarnybos motyvacija. Remiantis atlikto tyrimo analize teigiama, kad esama kariu tarnybos motyvacijos sistema patys kariai patenkinti tik iš dalies. Taip pat tyrimo rezultatai igalina patvirtinti suformuluota hipotezę, leidžiančia teigti, kad savanoriškai ir privaloma tvarka atliekančiu NPPKT kariu tarnybos motyvacija skiriasi, kadangi ju karo tarnyba sqlygojantys lūkesčiai nèra tapatūs.
\end{abstract}

Pagrindiniai žodžiai: nuolatinè privalomoji pradinè karo tarnyba, kariai, tarnybos motyvacija.

\section{Ivadas}

Svarbiausių ir reikšmingiausių pasaulio ịvykių grandinèje karas ir kariuomenė vaidina išskirtinị vaidmenį. „Gynybą nuo išorinių (pirmiausia karinių) grèsmių užtikrina valstybè, o valstybès - pagrindiniai tarptautinių santykių objektai, tarptautiniams santykiams esant anarchinès būklès, nuolat siekia didinti galią, kad užsitikrintų saugumą" (Jokubauskas, 2014: 13). Valstybès turi gebėti aktualizuoti ir formuoti individualius ir kolektyvinius kompleksinius saugumą užtikrinančius veiksmus.

Kariuomenę sudaro kariai, o karys yra lankstus išteklius, kuris priklausomai nuo kuriamos aplinkos gali veikti blogiau arba geriau, tokiu būdu aktualūs darosi motyvacijos reiškiniai, apie kuriuos diskutuoja ne tik mokslininkai, bet ir visuomenè. Motyvacija yra svarbus procesas, keičiantis organizacinès sistemos elgseną. Be to, motyvacija yra subjektyvus apsisprendimas ir požiūrio dalykas (neatmetant prielaidos, kad subjektyviai pozicijai ịtaką daro tam tikri veiksniai). Todèl tarnybos motyvavimas yra vienas iš reikšmingiausių determinantų vykdant praktiškai pokyčius, tobulinant krašto apsaugos sistemą. Kaip teigia Krašto apsaugos ministerijos 
(toliau - KAM) Gynybos planavimo departamento vedeja K. Šapkinaite, karių motyvacijos klausimas aktualesnis, negu klausimas apie ginklus ar įrangą (pagal Jonušą, 2018). Krašto apsaugos ministras R. Karoblis pabrèžia, kad kario motyvacija yra visa ko kariuomenèje pagrindas (pagal Jakilaitị, 2017).

Pasikeitus geopolitinei situacijai, $2015 \mathrm{~m}$. buvo sugrąžinta šauktinių tarnyba, kuri buvo 2008 m. nutraukta. Per ši laikotarpi, kai nebuvo privalomosios pradinés karo tarnybos, Lietuvoje egzistuojančios karinės tarnybos formos (Krašto apsaugos savanorių pajègos, baziniai kariniai mokymai, profesinè karo tarnyba, jaunujų vadu kursai) tuo metu rèmèsi savanoriškumo principu (Vileikienè ir kt., 2015). Tačiau remiantis KAM duomenimis, nuo $2015 \mathrm{~m}$. turime vèl ne tik karius savanorius, bet ir karius prievolininkus, nes nuolatinès privalomosios pradinès karo tarnybos karių tarnyba grindžiama ne tik savanoriškumo principu, bet ir prievarta (už šaukimo atlikti privalomąją pradinę karo tarnybą vengimą įstatymai numato bausmes). Pripažįstant karių tarnybos motyvacijos svarbą, formuojasi poreikis ieškoti teorinių ir empirinių patvirtinimų, kurie, kaip atspirties taškas, leistų įvertinti karių tarnybos motyvaciją.

Kalbant karine tematika išskirti verta C. Moskos'o (1977) karinę sociologiją. Jis analizavo kariuomenès instituto kaitą, ją susiedamas su karių motyvacijos svarba. Vèliau prie jo darbų tobulinimo prisidèjo F. Battistelli (1997), Y. Levy (2007) ir kt. Lietuvos kariuomenès karių tarnybos motyvacijos tematika atliktų tyrimų nëra gausu, tai lemia griežtas vyriausybinių institucijų kontroliavimas. Paminètina Generolo Jono Žemaičio Lietuvos karo akademijos Karo mokslų instituto Strateginių tyrimų centro parengta mokslo studija „Motyvacija tarnauti Lietuvos kariuomenėje“ (2015). Vienas naujausių tyrimų - A. Pocienès (2018) straipsnis „Lietuvos jaunuolių pritraukimo ị nuolatinę privalomają pradinę karo tarnybą galimybės“. Kol kas trūksta mokslinès medžiagos apie tai, kokia reali Lietuvos kariuomenės karių tarnybos motyvacija ${ }^{1}$.

Tiriamosios problemos esmę sudaro faktas, kad krašto apsaugos sistemoje neịmanoma įvykdyti efektyviai užsibrèžtu tikslų be karių skirto laiko ir pastangų indẻlio. Šiuo atveju išryškejja karių tarnybos motyvacijos svarba. Valdžios institucijų darbas nèra tik taikyti sankcijas, bet svarbu skatinti pačius karius ịsitraukti ị bendrą veiklą. Norint juos įtraukti, būtina išsiaiškinti lūkesčius, kodẻl kariai apsisprendžia dalyvauti arba lieka pasyviais tarnyboje. Mokslinè ir praktinė problema formuluotina klausimu, kas sąlygoja nuolatinę privalomają karo tarnybą atliekančių karių tarnybos motyvaciją ir kaip jie vertina dabartinę Lietuvos kariuomenės mo-

\footnotetext{
1 Pažymėtina, kad Lietuvos kariuomenès karių ir karininkų, taip pat motyvacijos tyrimai atliekami ir magistrų baigiamujų darbų lygiu (Razma G. (2014). Profesinès karo tarnybos karininku žiniu vertinimas. Žmonių išteklių vadybos studijų programos magistro baigiamasis darbas. Vilnius, Generolo Jono Žemaičio Lietuvos karo akademija; Vasiljevas E. (2015). Tarnybos Lietuvos krašto apsaugos savanoriu pajegose motyvu analize. Taikomosios sociologijos studiju programos magistro baigiamasis darbas. Kaunas, Vytauto Didžiojo universitetas; Baltutyte G. (2019). Lietuvos kariuomenès kariu tarnybos motyvacijos analize nacionalinio saugumo kontekste. Nacionalinio saugumo studijų programos magistro baigiamasis darbas. Klaipėda, Klaipėdos universitetas).
} 
tyvavimo sistemą?

Tyrimo tikslas - išanalizuoti nuolatinès privalomosios pradinès karo tarnybos (toliau - NPPKT) karių tarnybos motyvaciją, atskirai tiriant karius, kurie ją atlieka privaloma tvarka, ir karius, savanoriškai pasirinkusius atlikti NPPKT.

Remdamasi tiek teorinemis prielaidomis, tiek empiriniais tyrimais keliu hipotezę, kad savanoriškai ir privaloma tvarka atliekančių NPPKT karių tarnybos motyvacija turi skirtis, nes jų karo tarnybą sąlygojantys lūkesčiai nèra tapatūs. Didesnès esminès įtakos karo tarnybos motyvacijai turi savanoriškumo principu grindžiamas atèjimas ị karo tarnybą.

Tyrime taikyti mokslinès literatūros ir dokumentų analizès bei duomenų kaupimo anketinès apklausos metodai.

\section{Karių tarnybos motyvacija}

Didejanti motyvacijos reikšmè skatina nagrinèti karių tarnybos motyvaciją. Nuo seniausių laikų armijų vadai susidūrè su kareivių ir naujokų motyvacijos problemomis (Statkus, 2003). Dažniausiai motyvacija siejama su lotynų kalbos žodžiu motivere, kuris reiškia judėjimą, veiksmą, veiklos priežastį, elgseną. R. Semler (2003), F. Malik (2005) teigia, kad motyvacija yra jèga, kuri išjudina ir nukreipia žmogų, pasirenkantị tam tikrą veiklą bei pastangų intensyvumą (pasak Marcinkevičiūtès, 2010: 40). Panašiai motyvaciją apibrèžia ir D. Lipinskienė (2012). Tai jèga, kuri suteikia individui energiją ir kryptį tam tikrai jo elgsenai ir yra siekio ir nusiteikimo pagrindas veikti toliau, susidūrus su kliūtimis. Taigi motyvacija grindžiama nuostata, kad ji ịkvepia ir stumia žmogų ị priekị, kad būtų pasiekti jo užsibrèžti tikslai.

Remiantis Generolo Jono Žemaičio Lietuvos karo akademijos Karo mokslų instituto Strateginių tyrimų centro parengta mokslo studija „Motyvacija tarnauti Lietuvos kariuomeneje“, siekiant suprasti ir paaiškinti karių motyvaciją, analizuojama A. H. Maslow'o teorija, akcentuojant individų poreikių hierarchiją. Tačiau autorè nori pažymèti, kad asmenys, atlikdami karo tarnybą, turi ne tik poreikius, bet ir tam tikrų lūkesčių, kurie gali būti motyvacijos įrankiu tarnybos metu. Kaip nurodo J. L. Perry'is (1996), kiekvienas atsineša ị instituciją savo „lūkesčių krepšelį“, o vadovybei svarbu identifikuoti „krepšelio“ turinį. Nepateisinti lūkesčiai gali būti kliuvinys sėkmingai ir motyvuotai tarnybai. Analizuojant karių tarnybos motyvaciją, remiamasi žinomiausia proceso motyvacijos teorija - V. H. Vroom‘o lūkesčių teorija, kurioje pabrezžiama, kad elgesys kyla iš sąmoningo pasirinkimo tarp alternatyvų, kurių tikslas yra maksimaliai padidinti malonumą ir sumažinti skausmą. V. H. Vroom'as teigia, kad žmogaus veikla grindžiama individualiais veiksniais, tokiais kaip asmenybè, iggūdžiai, žinios, pastangos, gebèjimai. Būtina atsižvelgti, kad pastangos ir veiklos rezultatai yra susiję su asmens motyvacija, todèl jis išskyre kintamuosiuos veiksnius (lūkesčiai, instrumentalumas, valentingumas) kaip pagrindą motyvacijai. Kadangi žmogaus elgesys turi įtakos institucijos veiklai, 
lūkesčių teorijos autorius pastebejjo, kad jei darbdavys mano, kad suteikė viską, kas reikalinga motyvacijai, ir tai veikia daugeliui žmonių, visgi nereiškia, kad tai veiks absoliučiai kiekvieną dirbantį toje organizacijoje. Be to, žmogus dar turi tikèti, kad pasirinkta elgsena iš tiesų galès patenkinti jo lūkesčius (Sakalas, 2000). Stumbraitè-Vilkišienè (2013), remdamasi V. H. Vroom‘o teorija, teigia, kad piliečiai, prieš pradėdami dalyvauti, pirmiausia svarsto, ko jie tikisi ir ko reikia, kad pasiektų tai, ko trokšta, ar jie turi tam gebejjimų, ar jiems tai aktualu. Kartu ịvertina, ką duos jų pastangos. Kita vertus, piliečiai turi vertinti dalyvavimo tikslą, problemą. Ši teorinè prieiga yra tinkama interpretuojant ir ieškant atsakymo, ar karių lūkesčiai pasiteisino karo tarnyboje. Būtina išskirti ir tai, kad Lietuvoje jaunus žmones stengiamasi motyvuoti ateiti tarnauti: „NPPKT yra puikus būdas atlikti pareigą Tèvynei, neprilygstamas nuotykis ir geras finansinis postūmis gyvenimo pradžiai. Savo noru tarnybą atliekantis karys gali pasirinkti ir tarnybos vietą: veiksmo kupiną pėstininko kelią, griausmingą ir paraku dvelkiantį artileristo darbą, technikos žinias lavinantị ryšininko darbą bei kitas, ne mažiau įtraukiančias tarnybas kituose kariniuose vienetuose visoje Lietuvoje“" (www.karys.lt). Nors kariams siūlomos realios galimybės, kurios juos asmeniškai gali sudominti, tačiau autorè mano, kad ị klausimą „kodèl jie tai turi daryti?" atsakymo turi nuolatos ieškoti ne tik ateinantys tarnauti, bet ir jau tarnaujantys kariai bei valdžios institucijos, kurios siekia ịgyvendinti savo strategiją.

J. Griffith'as (2008), tyrinèdamas jaunimo ir aktyvių karių motyvaciją tarnauti kariuomeneje, savo darbuose rémèsi 2 motyvacijos tipais: institucinis (patriotizmas, siekis save išbandyti, noras būti naudingam valstybei ir visuomenei) ir pragmatinis (kariuomene kaip darbdavys, kuris teikia viliojančius pasiūlymus). Šiuo požiūriu asmenys tarnauja kariuomenèje dèl materialių ar nematerialių motyvų. Anot P. Bury'io (2017) ir kitų autorių, kariai su pragmatine motyvacija yra mažiau patenkinti tarnybos sąlygomis. Dažnai teigiama, kad karių motyvacijai skatinti trūksta lěšų, tačiau galima prielaida, kad nežinoma, kaip be papildomų lëšu skatinti ir išlaikyti karių tarnybos motyvaciją. T. D. Woodruff'as (2017) pastebi, kad savanoriški įsitraukimo tikslai - tiek vidiniai, tiek išoriniai - gali suteikti milžinišką motyvaciją kariams. Apibendrinus autorių mintis galima išskirti, kad motyvacija apima sąmoningą norą ką nors gauti ir ji neapsiriboja vien pinigais ar noru išvengti bausmès.

Kita vertus, asmenys ne visada supranta tuos motyvus, kurie juos skatina, tačiau žino siekiamus savo tikslus. Taip pat motyvacija turi dvi svarbias sudedamąsias dalis: impulsą ir pati motyvą. Impulsas yra vidinis procesas, kuris skatina veikti, o motyvas generuoja elgesị ir padeda žmogui siekti jo tikslo, kuris kaip atlygis ịprastai tenkina asmens vidinius reikalavimus (Rodrigues - Goulart, 2006). Tuo tarpu D. Lipinskienè (2012) išskiria, kad motyvaciją skatina trys pagrindiniai veiksniai: veiklos (tikslų) nustatymas, veiklos palengvinimas (aprūpinimas būtinais ištekliais, barjerų eliminavimas), skatinimas (atlygio savalaikiškumas, teisingumas, lygybè, reikšmingumas ir poreikių tenkinimas). Jei šie universalūs veiksniai yra igyvendi- 
nami, gali būti patenkinti žmonių lūkesčiai. Tačiau motyvacija nėra nuolatinè būsena, dèl kintamumo ją reikia periodiškai papildyti. Tiek motyvacijos teorija, tiek praktika remiasi nuostata, kad motyvacija gali „,išsisklaidyti“ (Žaptorius, 2007). Be to, objektyviai gerejjant gyvenimo sąlygoms, dideja ir žmonių jautrumas ịprastiems sunkumams. Tad rezultatas yra ne pasitenkinimas, bet įtampa ir nuovargis arba nuobodulys, persisotinimas ir neviltis (Kuzmickas, 2018). Tai ịvertinus galima teigti, kad motyvacija yra subjektyvi savo esme, todèl institucija susiduria su nelengva užduotimi, kaip organizuoti, palaikyti ir nuolat gerinti motyvacinę sistemą, iš kurios reikalaujama, kad būtų vykdoma ne tik efektyvi ir sèkminga institucijos veikla, bet ir būtų patenkinti žmonių lūkesčiai. Juolab kad motyvacija gali būti priskirta latentiniams reiškiniams, kai tiriant nèra garantijų, kad matuojami dydžiai galès būti išreiškiami ir tai nulems žmonių pažiūras ir elgesị (Marcinkevičiūtè, 2010). Tačiau aišku, kad veiksminga motyvavimo sistema yra puiki priemonè, norint kariuomenei maksimaliai išnaudoti savo pajègumus, palaikyti kovinę parengtį.

Iprastai kariuomenė grindžiama biurokratiniu valdymu, todèl mokslininkai ịžvelgia tokios struktūros reformavimo ir tobulinimo poreikį. Šiuo metu krašto apsaugos sistemoje kariams taikomos suformuotos motyvacijos veiklos yra abstrakčios ir nekonkrečios. Todèl galima tikètis ir tokių pat neaiškių rezultatų motyvacijos procese. Taigi sudarant perspektyvinius karių motyvacijos planus yra svarbu, kad visi kariai (individualiai) būtų motyvuoti siekti kariuomenès veiklos tikslų. Suvokus, kad kariai sieks tikslų tik tuomet, jei patenkins ir savo lūkesčius, kariuomenès vadovybè turi priimti iššūkị ir tobulinti savo motyvacinę sistemą taip, kad gebètų ne tik pritraukti, bet ir kuo ilgiau išlaikyti tarnyboje šiuolaikinị karị. R. Steiger' is ir U. Zvygard'as (1999) teigia, kad reikia daryti viską, kad karo tarnyba būtų patrauklesnè ir veiksmingesnè, tačiau reikia atminti, kad karo tarnyba yra visgi tarnyba. Taip pat verta paminèti, kad tarnybos motyvacijos koncepcija susijusi su tam tikro laikotarpio nacionalinio saugumo samprata.

\section{Nacionalinio saugumo samprata}

Visuotinai priimto nacionalinio saugumo apibrèžimo nèra, todèl tiek mokslinèje literatūroje, tiek kasdienybèje apibrěžiama ši sąvoka skirtingai. Nepolemizuojant su B. Buzanu, ,pati saugumo sąvokos prigimtis neleidžia suformuoti tikslaus jos apibrèžimo“", nes ji susieja skirtingus saugumo lygmenis (Buzan, 1997:49). Žvelgiant istoriškai, anksčiau, kaip teigia V. Jokubauskas, „valstybès saugumo sąvoka ne karo metu neturejjo prasmès ir politiniame diskurse iš esmès neegzistavo. Saugumo sąvoka tik XX a. buvo retrospektyviai susieta su valstybe, o pastaroji ekstrapoliuota ị visas istorines epochas kaip kažkas amžino, visada egzistavusio, be ko šiandien neįmanoma ịsivaizduoti pasaulio“ (Jokubauskas, 2014:14). Taigi seniau saugumas elementariaja prasme buvo suvokiamas kaip karo ar jo potencialios grèsmès nebuvimas.

Šiandien gyvename ne tik Lietuvoje, bet ir pasaulyje (Laurènas, 2017:108). 
Todèl nacionalinis saugumas tampa sudètingu daugiasluoksniu procesu, nes yra svarbi ne tik lokalizuota valstybès vieta. Dèl nacionalinio saugumo sampratos suvokimo raidos, dabar jis tradiciškai aiškinamas kaip valstybès suvereniteto išsaugojimo koncepcija, naudojant ir apjungiant šalies politines, ekonomines, socialines, karines, diplomatines galias, kurios apima gynybą nuo išorès priešų ir kitų grèsmių (Kazlauskaitė Markelienè ir kt., 2010: 237). Oficialiai Lietuvos nacionalinio saugumo samprata yra ịtvirtinta Lietuvos Respublikos nacionalinio saugumo pagrindu įstatyme. Jame teigiama, kad „Lietuvos nacionalinio saugumo užtikrinimas - tai tautos ir valstybės laisvos ir demokratinès raidos sąlygų sudarymas, Lietuvos valstybès nepriklausomybès, jos teritorinio vientisumo ir konstitucinès santvarkos apsauga ir gynimas“ (Nikartas, 2014:13). Todèl nacionalinio saugumo užtikrinimas tampa aukščiausiu valstybès vidaus ir užsienio politikos prioritetu.

Tačiau vykstant transformacijoms neišvengiamai formuojasi kitokia nuomonè ị tuos pačius objektus, nei buvo vakar (Razma, 2014). Atsižvelgiant ị tai, buvo atliekamas NPPKT karių tarnybos motyvacijos tyrimas nacionalinio saugumo kontekste.

\section{Tyrimo duomenys ir jų analizė}

Kariuomenė yra uždara institucija civiliams, todèl pirmiausia tyrimui atlikti buvo gautas Sausumos pajėgų pasirinkto bataliono vado leidimas atlikti tyrimą. $2018 \mathrm{~m}$. kovo mènesi atliktas kiekybinis tyrimas, anoniminė anketinė apklausa. Remiantis mokslo informacijos šaltiniais parengtas klausimynas nuolatinès privalomosios pradinès karo tarnybos kariams. Tyrimo instrumentą, kuris sudarytas autorès, sudaro 30 uždaro ir atviro pobūdžio klausimų.

Pasirinkti respondentai buvo nuolatinès privalomosios pradinès karo tarnybos kariai, atliekantys pradinę karo tarnybą viename Lietuvos kariuomenès Sausumos pajègų batalione. İ tokị kiekybinio tyrimo ribojimą būtina atsižvelgti apibendrinant tyrimo rezultatus.

Tyrimo imčiai sudaryti taikyta tikimybinė paprastoji atsitiktinė vienmomentė tiriamųjų karių atranka. Imties dydis prieš apklausą $\mathrm{n}=579$ kariai, po apklausos $\mathrm{n}=561$ karys $(96,89$ proc.). Sukeliant duomenis ị SPSS17 statistinę programą pastebèta, kad dalis anketų buvo užpildytos iš dalies arba nekorektiškai, todèl ị tyrimo duomenų analizę nebuvo ịtrauktos. Tiriamųjų duomenų analizèje naudojamos 507 respondentų užpildytos anketos. Nagrinèjant pasirinktą tyrimo imtį nustatyta, kad išsiskyrè karių atèjimas ị tarnybą: daugiau nei pusè $(60,9$ proc. $n=309)$ karių teigè, kad tarnauti atejjo savanoriškai, o likusi dalis $(39,1$ proc. $n=198)$, kad atejjo tarnauti dèl privalomos tvarkos. Tyrime dalyvavo tiek moterys $(4,54$ proc. $\mathrm{n}=23)$, tiek vyrai $(95,46$ proc. $n=484)$, dažniausiai tiriamujų žymėtas amžius buvo nuo 21 iki $26 \mathrm{~m}$. (54 proc. $\mathrm{n}=274)$, mažiau žymètas - iki $21 \mathrm{~m}$. $(43,2$ proc. $\mathrm{n}=219)$ ir labai maža dalis - nuo 27 metų ir daugiau $(2,8$ proc. $n=14)$. Analizuojant duomenis apie respondentų išsilavinimą, atsakymo variantai pasiskirste šitaip: daugiau negu pusė 
turi vidurinị ( 54 proc. $\mathrm{n}=279)$, trečdalis - vidurinị specialujj profesini $(33,5$ proc. $\mathrm{n}=170)$, mažiau nei dešimtadalis - aukštaji neuniversitetini $(6,7$ proc. $\mathrm{n}=34)$ arba aukštąi universitetini $(5,3$ proc. $n=27)$ išsilavinimą.

Tiriamieji norą dalyvauti tyrime patvirtino žodiniu sutikimu. Atsižvelgiant i faktinius argumentus, tyrimas atliktas lokalizuotoje vietoje, tačiau imtis reprezentatyvi, todèl gauti rezultatai leido atspindèti NPPKT karių tarnybos motyvacijos probleminę situaciją. Toliau pateikiami tyrimo rezultatai.

\subsection{Tyrimo rezultatai}

Pirmiausia siekta išsiaiškinti karių patriotinius motyvus ir atsakomybę dèl nacionalinio saugumo užtikrinimo. Karių buvo klausiama, jei kiltų reali karinè grèsmé Lietuvai, ar eitų ją ginti. Daugelis savanoriškai tarnybą pasirinkusių teigia (67,64 proc.), kad eitų ginti šali, jei kiltų karinè grèsmè, mažesnè dalis (19,74 proc.) neturi nuomonès arba nèra apsisprendę, o mažiausioji dalis (12,62 proc.) teigia, kad neprisidètų prie šalies gynybos. Privaloma tvarka tarnaujančių karių rezultatai atskleidžia, kad mažiau nei pusė $(45,96$ proc.) eitų ginti šali, trečdalis $(29,29$ proc.) neturi nuomonès arba nèra apsisprendęs, ketvirtadalis (24,75 proc.) teigia, kad negintų šalies, atsiradus realiai karinei grèsmei. Skirtumas tarp šių grupių yra statistiškai reikšmingas.

Taip pat buvo klausiama, kokie NPPKT karių tarnavimo kariuomenèje motyvai. Nustatyta, kad dažniausiai NPPKT kariai pasirinko tarnybą, nes nori igyti karinių žinių ir praktinių igūdžių (36,5 proc.) arba buvo pašaukti atlikti NPPKT (32,7 proc.), daugiau nei dešimtadalis pasirinko dèl galimybès realizuoti savo sugebejjimus ir patirti (13,4 proc.), nedidelè dalis pasirinko, nes turi norą ginti Tẻvynę $(6,7$ proc.) ar dèl patriotizmo (6,1 proc.), mažiausiai karių pasirinko tarnybą dèl tinkamo užmokesčio (3,2 proc.), nedarbo (2 proc.) arba todèl, kad tarnyba nereikalauja didelès atsakomybès $(1,4$ proc.). Taip pat buvo aktualu išsiaiškinti, ar savanoriškai ir privaloma tvarka tarnaujantys kariai yra patenkinti atejję ị Lietuvos kariuomenès tarnybą. Tyrimo rezultatai leidžia teigti, kad dauguma savanoriškai tarnaujančių karių yra patenkinti (43,04 proc.), truputị mažiau teigia, kad nei taip, nei ne (41,42 proc.), ir maža dalis - nepatenkinti (15,53 proc.). Visai kitaip mano privaloma tvarka tarnaujantys kariai: didžioji dalis žymèjo savo atsakymuose nei taip, nei ne (47,47 proc.), daugiau nei trečdalis - nepatenkinti (39,39 proc.) ir tik maža dalis yra patenkinti (13,13 proc.), kad atejo ị Lietuvos kariuomenés tarnybą. Skirtumas tarp šių grupių yra statistiškai reikšmingas. Ar kariai būtų tarnavę kariuomenèje, jei nebūtų šauktinių prievolès, paaiškejjo, kad daugiau nei pusė teigia, kad netarnautų (57,4 proc.), kiek mažesnè dalis teigia, kad tarnautu (42,6 proc.) kariuomenèje, jei nebūtų šauktinių prievolès.

Karių buvo paprašyta, kad jie prisimintų savo pirmajị ịspūdị apie tarnybą ir nurodytų, kaip jie ją vertina dabar. Atsakymai matyti 1 paveiksle. 


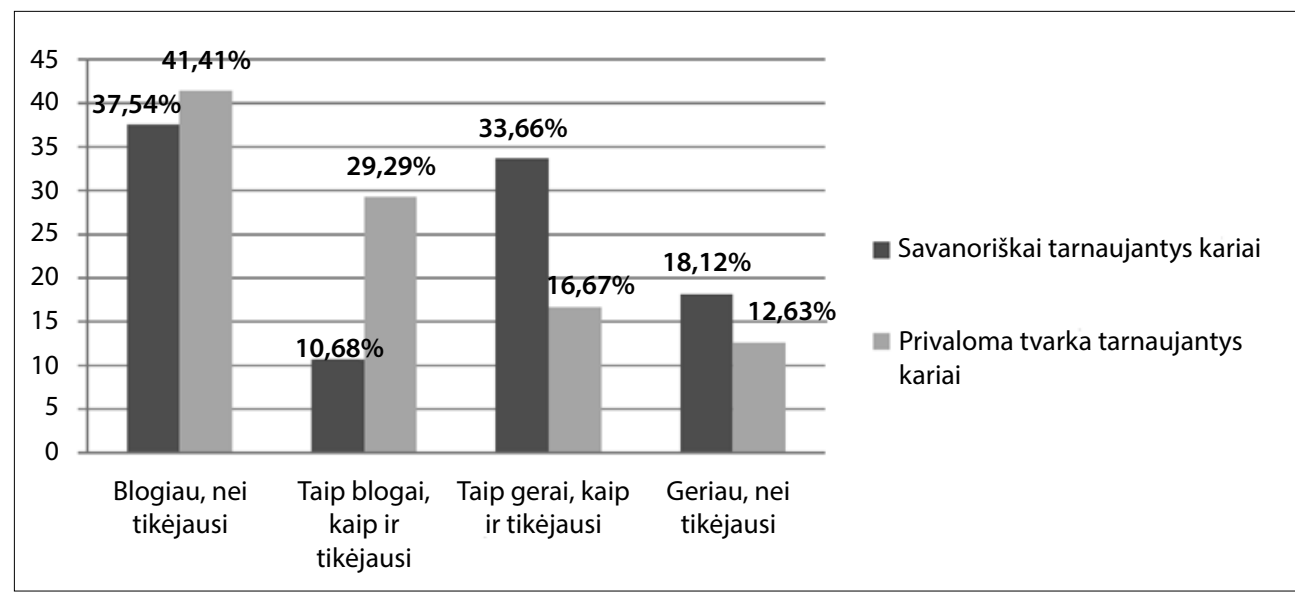

1 pav. Savanoriškai ir privaloma tvarka tarnaujančių karių pirmasis ịspūdis apie tarnybą

Daugiausia privaloma tvarka tarnaujančių (41,41 proc.) ir savanoriškai tarnybą pasirinkusių (37,54 proc.) teigia, kad lyginant su pirmu įspūdžiu ir tarnyba dabar, ją vertina blogiau, nei tikejjosi. Taip blogai, kaip ir tikejjosi, vertina beveik trečdalis privaloma tvarka tarnaujančiu $(29,29$ proc.) ir dešimtadalis savanoriškai tarnybą pasirinkusių (10,68 proc.). Taip gerai, kaip ir tikejosi, vertina trečdalis savanoriškai tarnybą pasirinkusių (33,66 proc.) ir šeštadalis privaloma tvarka tarnaujančiu (16,67 proc.). Geriau, nei tikèjosi, vertina beveik penktadalis savanoriškai tarnybą pasirinkusių (18,12 proc.) ir truputi daugiau nei dešimtadalis privaloma tvarka tarnaujančių (12,63 proc.). Skirtumas tarp šių grupių yra statistiškai reikšmingas.

Ne mažiau įdomus buvo ir pačių karių savo tarnybos vertinimas. Daugiausia savanoriškai tarnybą pasirinkusių karių savo tarnybą ịvertino gerai: dienos tarnybos vykdymą (51,1 proc.), kovinio šaudymo pratybas (36,9 proc.), kolektyvinį karini rengimą kuopoje (49,5 proc.), individualų karinį rengimą (44,7 proc.), fizini pasirengimą ( 45,6 proc.). Tuo tarpu privaloma tvarka tarnaujančių karių rezultatai panašūs, jie taip pat ịvertino gerai: dienos tarnybos vykdymą (50,0 proc.), kovinio šaudymo pratybas (33,8 proc.), individualų karinị rengimą kuopoje $(42,4$ proc.), fizinị pasirengimą $(47,0$ proc.) ir tik kolektyvini pasirengimą kuopoje $(37,4$ proc.) daugiausia prievolininkų įvertino patenkinamai. Nustatyta, kad NPPKT kariai išskiria šiuos gebejjimus, kurie reikalingi kariui tarnyboje: gebejjimą greitai vykdyti paskirtą užduotị (79,7 proc.), kiek mažiau žymèjo gebejjimą laiku užbaigti pradètą užduotị (66,1 proc.) ir gebejjimą vadovauti, kontroliuoti (64,7 proc.), truputi daugiau nei pusè - gebėjimą mokyti kitus (56,6 proc.) ir gebèjimą numatyti užduočiu perspektyvas (53,6 proc.), truputi daugiau nei trečdalis - gebejimą diegti inovacijas $(36,1$ proc.), maža dalis - kita ( 8,9 proc.). Taip pat buvo paklausta, kokios savybės labiausiai trūksta NPPKT kariams. Dažniausiai NPPKT kariai ịvardijo, kad trūkta aktyvumo ir iniciatyvumo (23,1 proc.), patriotizmo (22,3 proc.), pagarbos (19,1 proc.), kiek mažiau - nieko netrūksta (12,2 proc.), pasitikèjimo savimi ( 9,3 proc.), sąžinin- 
gumo (7,1 proc.), mažiausiai - drąsos (3,6 proc.), principingumo ( 3,4 proc.).

Analizuojant vieną svarbiausių karių tarnybos motyvacijos klausimų, buvo paklausta respondentų, ar būtinas kario motyvavimas. Absoliuti dauguma karių 84 proc. teigia, kad būtina kario motyvacija, nes tik gerai motyvuotas karys siekia ir pasiekia gerų rezultatų. Tik dešimtadalis $(10,1$ proc.) teigia, kad pakanka vidutinès motyvacijos, ir maža dalis $(5,9$ proc.) nesuteikia tam reikšmès. Tikslinga pažymèti, kad esama Lietuvos kariuomenès karių tarnybos sistema puse karių iš dalies patenkinti (50,3 proc.), kiek mažiau negu pusè - nepatenkinti (44,6 proc.) ir tik labai maža dalis yra patenkinti (5,1 proc.). Kadangi tik labai maža dalis karių yra patenkinti Lietuvos kariuomenès tarnybos motyvacijos sistema, buvo kariams įvardytos priežastys, dèl kurių jie iš dalies arba visiškai nepatenkinti šiuo metu esama motyvacijos sistema. Trečdalis respondentų ịvardijo, kad netobula skatinimo sistema (33,9 proc.), kiek mažiau pažymejjo, kad kartais skatinami ne tie kariai, kurie nusipelno (26,4 proc.), daugiau nei dešimtadalis - ne visada aišku, už ką skatinama (15,8 proc.) arba gaunami tik padèkos raštai, kurie nieko verti (14,2 proc.), mažiausiai - kita (6,3 proc.). Buvo siekiama išsiaiškinti, ar patys kariai jaučiasi motyvuoti siekti gerų rezultatų tarnyboje ( 2 pav.).

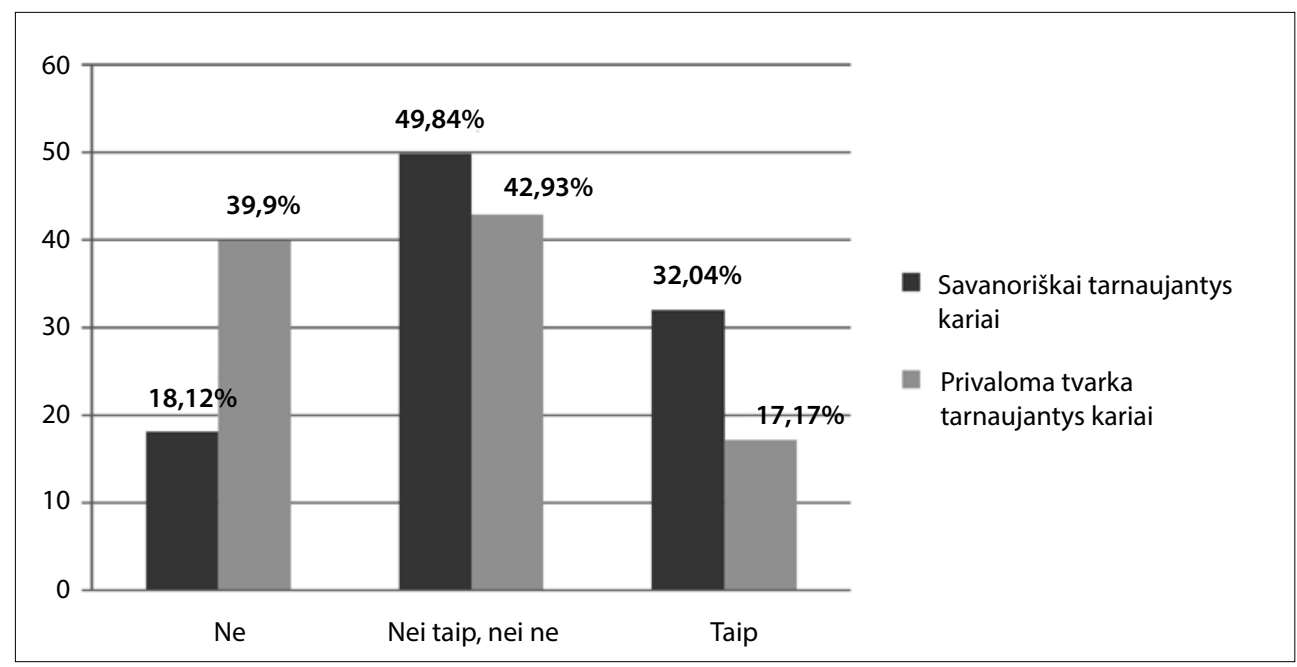

2 pav. Savanoriškai ir privaloma tvarka tarnaujančių karių motyvacija siekti gerų rezultatų tarnyboje

Daugiausia atsake savanoriškai tarnybą pasirinkusių $(49,84$ proc.) ir privaloma tvarka tarnaujančių (42,93 proc.), kad nei jaučia, nei nejaučia motyvacijos siekti gerų rezultatų tarnyboje, tuo tarpu daugiau jaučia motyvaciją savanoriškai tarnybą pasirinkę kariai (32,04 proc.), nei privaloma tvarka tarnaujantys kariai (17,17 proc.), o nejaučia daugiau privaloma tvarka tarnaujantys kariai (39,90 proc.), nei savanoriškai tarnybą pasirinkę kariai (18,12 proc.). Skirtumas tarp šių grupių yra statistiškai reikšmingas. Kartu statistinès analizès rezultatai rodo, kad karių motyvaciją mažina: 
neracionalus tarnybos organizavimas (27,4 proc.), neįdomi tarnyba (17,4 proc.), per mažas užmokestis (17,2 proc.), kiek mažiau karių pažymèjo, kad tarnyba reikalauja didelès nervinès įtampos (14 proc.), mažiau nei dešimtadalis - varginanti tarnyba (9,1 proc.), nevienodai paskirstytas tarnybos krūvis $(9,1$ proc.), kita ( 6,1 proc.).

Kitas aspektas, kuris aktualus, kad NPPKT kariai tarnautu geriau. Didžioji dalis respondentų teigia, kad tarnautu geriau, jei tarnyba teiktų malonumą (30,2 proc.) arba tarnybos krūvis atitiktų užmokestị (22,9 proc.), kiek mažiau - tarnauja ir taip gerai (15,8 proc.) arba geriau tarnauti nemato reikšmès (13,0 proc.), mažiausiai - jei turètų daugiau sugebejjimų ( 6,7 proc.), jei turètų daugiau fizinès ištvermès $(6,5$ proc.), jei matytų realias karjeros galimybes ( 4,9 proc.). Taip pat tarnybos motyvacijai ịtaką daro ir nematerialūs skatinimo būdai. Būdingas gana ryškus išskyrimas, kad maloniausias nematerialus tarnybos skatinimo būdas - laisvadienis (70,4 proc.), nedidelè dalis pažymėjo pagyrimą ( 14,8 proc.), mažiausiai rūpi laisvalaikio programos (6,5 proc.), sudètingos užduoties paskyrimas (6,3 proc.), kita (2 proc.).

3 paveiksle matyti aktualus išsiaiškinimas, kaip vertina patys kariai krašto apsaugos pajègas.

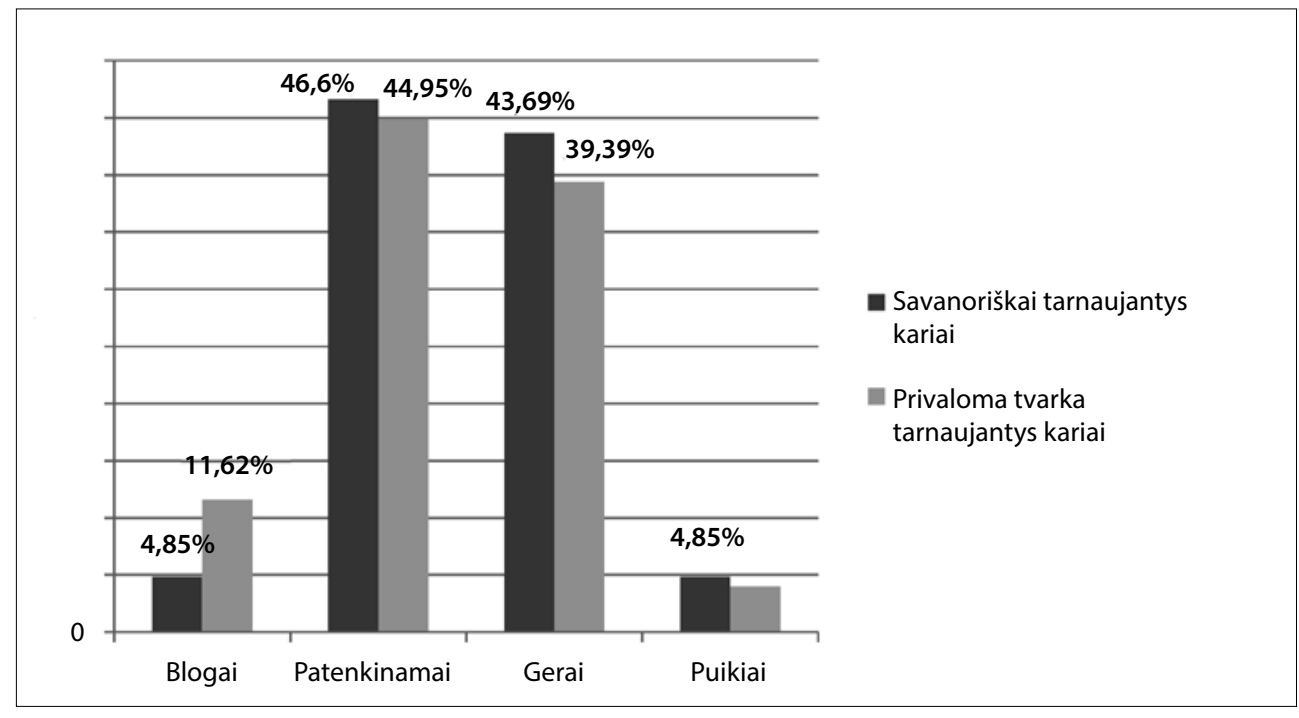

3 pav. Savanoriškai ir privaloma tvarka tarnaujančių karių Lietuvos krašto apsaugos pajègų vertinimas

Daugiausia savanoriškai tarnybą pasirinkę kariai krašto apsaugos pajègas vertina patenkinamai (46,60 proc.) arba gerai (43,69 proc.), o jų maža dalis - puikiai $(4,85$ proc.) ir blogai $(4,85$ proc.). Daugiausia privaloma tvarka tarnaujantys kariai krašto apsaugos pajègas vertina patenkinamai (44,95 proc.) arba gerai (39,39 proc.), dešimtadalis - blogai (11,62 proc.) ir maža dalis $(4,04$ proc.) - puikiai. Skirtumas tarp šių grupių yra statistiškai reikšmingas. Taip pat išsiaiškinta, 
kad didelè dalis $(67,68$ proc.) privaloma tvarka tarnaujančių karių išvis negalvoja apie tolesnę profesinę karo tarnybą, ketvirtadalis $(25,25$ proc.) - gal kažkada ateityje ir maža dalis $(7,07$ proc.) galvoja apie tolesnę profesinę karo tarnybą. Didesnè dalis (37,86 proc.) savanoriškai tarnybą pasirinkusių karių galvoja, kad gal kažkada ateityje eitu i profesinę karo tarnybą, trečdalis $(33,3$ proc.) negalvoja eiti, o kiek mažesnè dalis $(28,80$ proc.) galvoja apie tolesnę profesinę karo tarnybą. Skirtumas tarp šių grupių yra statistiškai reikšmingas.

Daug diskusijų keliantis visuomeneje ir valstybeje klausimas dèl visuotinio šauktiniu šaukimo vis dar yra neišspręstas, todèl buvo karių paklausta, kaip jie mano, ar būtų tikslingas visuotinis šaukimas. Beveik pusè $(49,1$ proc.) karių teigia, kad netikslingas būtų karių visuotinis šaukimas, kiek daugiau nei trečdalis (35,3 proc.) mano, kad tikslingas, o daugiau nei dešimtadalis (15,6 proc.) nežino, koks tinkamiausias būtų sprendimas.

Nepaisant vis didesnio skiriamo dèmesio ir išteklių kariuomenei, atlikto tyrimo rezultatai rodo, kad pasitenkinimas NPPKT tarnyba nèra toks jau didelis, ypač nepatenkinti privaloma tvarka tarnaujantys kariai, lyginant juos su savanoriškai tarnybą pasirinkusiais kariais.

\subsection{Tyrimo rezultatu aptarimas}

Atsižvelgiant ị NPPKT karių motyvus tarnauti išsiaiškinta, kad labiausiai priimtiną tarnavimo variantą respondentai pasirinko dẻl noro įgyti karinių žinių ir praktinių igūdžių. A. Pocienès (2018) moksliniame straipsnyje „Lietuvos jaunuolių pritraukimo ị nuolatinę privalomąją pradinę karo tarnybą galimybès" pateikti tyrimo rezultatai reprezentuoja 2015-2016 m. ,pirmosios bangos“ po NPPKT sugrąžinimo šauktinių nuomonę. Taigi pirmoji paskata tapti šauktiniu kariu - tai noras išmokti apginti savo šeimą, tėvynę esant grèsmei. Kitas pagal svarbą šauktiniams kariams noras - patirti nuotykių ir išbandymų. Lyginant šių dviejų tyrimų rezultatus galima teigti, kad NPPKT karių tarnybos motyvacija remiasi instituciniu motyvacijos tipu. Taip pat tyrimas atskleidžia, kad daugiau tarnybą yra patenkinti savanoriškai tarnybą pasirinkę kariai, nei privaloma tvarka tarnaujantys. Tačiau jei nebūtų šauktinių prievolès, dauguma karių teigia, kad išvis netarnautų kariuomenèje.

Remiantis V.H. Vroom'o lūkesčių teorija, galima teigti, kad tyrime dalyvavusių karių lūkesčiai buvo patenkinti tik iš dalies. Pažymėtina, kad, anot mokslo studijos „Motyvacija tarnauti Lietuvos kariuomenejje“ (2015) autorių, didžioji dalis Krašto apsaugos savanoriu pajègose tarnaujančių karių teigia, kad palyginus lūkesčius prieš tarnybą ir dabar, dauguma jų tarnybą vertina taip gerai, kaip ir tikejjosi.

Atkreiptinas dèmesys, kad kariai išskyrè šiuos reikalingus tarnyboje gebejjimus: greitai vykdyti paskirtą užduotị, laiku užbaigti pradėtą užduotị, vadovauti ir kontroliuoti. Dauguma savanoriškai tarnybą pasirinkę ir privaloma tvarka tarnaujantys kariai savo pastarujų mẻnesių tarnybą vertina gerai. Darbo autorei nebuvo galimybės palyginti šiuos rezultatus su karių vadų rezultatais, kaip jie vertintų tuos ka- 
rius. Tačiau interpretuojant šiuos duomenis, dera prisiminti V. H. Vroom'o lūkesčiu teoriją, kurioje pabrèžiama, kad norint pasiekti tam tikrų tikslų, reikalingi gebėjimai. Todèl autore daro prielaidą, kad kariai turi gebejjimų gerai vykdyti tarnybą, tačiau čia iškyla kitas probleminis klausimas, ar jie išnaudoja ši potencialą? Anot karių, jiems patiems pradineje karo tarnyboje labiausiai trūksta aktyvumo ir iniciatyvumo.

Kaip jau minèta teorineje dalyje, dèl tarnybos motyvavimo reikšmingumo atliktas tyrimas patvirtino, kad būtinas karių motyvavimas, nes tik gerai motyvuotas karys siekia ir pasiekia gerų rezultatų. Tačiau šiuo metu esama karių tarnybos motyvacijos sistema kariai patenkinti iš dalies, to dažniausios priežastys: netobula skatinimo sistema, kartais skatinami ne tie kariai, kurie nusipelno, ne visada aišku, už ką skatinama. Galima daryti prielaidą, kad jei kariai nebus tikri, kad jų tarnyba atlyginama teisingai, jie nesistengs siekti gerų tarnybos rezultatų, bendrų krašto apsaugos tikslų. Šie rezultatai suponuoja mintị, kad teoriškai pateikta kario motyvavimo sistema iš tikrujų visai kitaip veikia, nei galbūt tikimasi. Juolab kad patys kariai yra lyg ,pusiaukelèje“, nes dauguma ịvardijo, kad jaučiasi nei motyvuoti, nei nemotyvuoti siekti gerų tarnybos rezultatų. Todèl tai verčia analizuoti tarnybos motyvacijos sistemos trūkumus, o nustačius nepasitenkinimo priežastis - paprasčiau galima būtų rasti optimalius sprendimus, kurie tenkintų tiek karius, tiek vadovybę.

Taip pat nustatyti statistiškai reikšmingi ryšiai tarp to, kas mažina karių tarnybos motyvaciją, ir to, kas didina. Rezultatai rodo, kad labiau karių motyvaciją didina, jei tarnyba teikia malonumą arba tarnybos krūvis atitinka užmokestį, o atvirkščiai - ją mažina neracionaliai organizuota, neịdomi tarnyba ir per mažas užmokestis. Maloniausias nematerialus tarnybos skatinimo būdas - laisvadienis. Tokius rezultatus gavo ir KAM Karo psichologijos skyriaus psichologè kpt. Dainora Kasiliauskytė (2017), kai buvo atliktas tyrimas, kurio metu apklausti Kęstučio mechanizuotojo pėstininkų bataliono šauktiniai kariai. Išsiaiškinta, kad labiausiai karius motyvuoja ir palaiko galimybė savaitgaliais grį̌ti namo, o draudimas grįžti viena iš didžiausių bausmių.

Kariai Lietuvos krašto apsaugos pajègas vertina patenkinamai, o jų daugumos nuomone, visuotinis šaukimas nebūtų tikslingas. Taip pat baigus tarnybą, labiau savanoriškai tarnybą pasirinkę kariai galvoja pereiti ị profesinę karo tarnybą, nei privaloma tvarka tarnaujantys kariai. Ieškant sprendimo, kas pagerintų karių tarnybos motyvaciją, išskirtina, kad dèmesys turi būti skiriamas materialiam ir nematerialiam tarnybos skatinimui, labiau kvalifikuotam personalui, pratybu kokybei, aprūpinimui ir pačios motyvacijos didinimui. Šiuo atžvilgiu kariai, išreikšdami savo nuomonę, prisideda ne tik prie kariuomenès tarnybos vertinimo, bet ir neleidžia ignoruoti akivaizdžių tiesų.

Atliktas kiekybinis tyrimas leido patvirtinti hipotezę, kad savanoriškai ir privaloma tvarka atliekančių NPPKT karių tarnybos motyvacija skiriasi, nes jų karo tarnybą sąlygojantys lūkesčiai nèra tapatūs. Didesnès, esminès karo tarnybos motyvacijai ịtakos turi savanoriškumo principu grindžiamas atèjimas ị karo tarnybą.

Apibendrinant galima teigti, kad interpretacijos, kurias autorè pateikè, gali 
būti suprantamos kitaip. Tačiau siekiama problemą neuždaryti, o atverti naujas interpretacijos perspektyvas. Todėl nagrinėjant karių tarnybos motyvacijos klausimą, vis dar yra erdvès ekspertams ir mokslininkams teikti pasiūlymus ir rekomendacijas, kad karių tarnybos motyvacijos rezultatai būtų geresni.

\section{Išvados}

Motyvuota karo tarnyba, bendrai kuriant ir užtikrinant šalies karines galimybes, sietina su tarnaujančiais kariais, kurie igyvendina karinio saugumo strategijas ir lemia vykdomos veiklos kokybinius rezultatus ir efektyvumą. Atliktas tyrimas atskleide, kad NPPKT karių lūkesčiai tarnyboje pasiteisino tik iš dalies. Suvokus, kad kariai sieks tikslų tik tuomet, jei patenkins ir savo lūkesčius, aktualu ieškoti įvairių būdų, kurie motyvuotų karių tarnybą. Svarbus vertybinių nuostatų vaidmuo - karinès vertybès sustiprina ir suvienija karius kaip asmenybes. Vertinant empirinio tyrimo rezultatus, NPPKT kariai išskyrè, kad labiausiai jiems patiems trūksta aktyvumo ir iniciatyvumo.

Šiuo metu krašto apsaugos sistemoje kariams taikomi motyvacijos veiksniai, kurie yra abstraktūs ir nekonkretūs. O atliktų mokslinių tyrimų ar studijų dar maža, kad būtų galima pagrịsti dabartinès motyvacijos sistemos (ne)sèkmingus ịgyvendinimo rezultatus. Remiantis lokalaus empirinio tyrimo rezultatais nustatyta, kad šiuo metu esama karių tarnybos motyvacijos sistema respondentai patenkinti iš dalies. İvertinus kiekybinio tyrimo rezultatus bei apsiribojant išskirtais instituciniu ir pragmatiniu motyvais, daroma išvada, kad NPPKT karių tarnybos motyvacija remiasi instituciniu motyvacijos tipu.

Tarnybos motyvacijai ypatingos įtakos turi savanoriškumo principu grindžiamas atejimas ị karo tarnybą. Savanoriškai tarnaujantys kariai yra labiau patenkinti tarnyba ir turi geresnị ịspūdi apie ją, yra labiau motyvuoti siekti gerų rezultatų tarnyboje, palankiau vertina krašto apsaugos pajègas ir galvoja apie tolesnę profesinę karo tarnybą, nei privaloma tvarka tarnaujantys kariai.

\section{Literatūra}

Bury, P. (2017). Recruitment and Retention in British Army Reserve Logistics Units. Armed Forces \& Society, Vol. 43 (4). P. 608-631.

Buzan, B. (1997). Žmonès, valstybès ir baimè. Vilnius: Eugrimas.

Griffith, J. (2008). Institutional motives for serving in the US Army National Guard: Implications for recruitment, retention, and readiness. Armed Forces \& Society, Vol. 34. P. 230-58.

Išbandyk save. (2016). Specialus Lietuvos kariuomenès žurnalo KARYS priedas būsimiems kariams. Prieiga: file:///C:/Users/Vartotojas/Downloads/isbandyk\%20save_.pdf

Jakilaitis, E. (2017). R. Karoblis: nežinia, kiek ilgai kario tarnyba ịkvèps vien patriotizmas. Prieiga: http://www.bernardinai.lt/straipsnis/2017-11-24-r-karoblis- 
nezinia-kiek-ilgai-kario-tarnyba-ikveps-vien-patriotizmas/166441.

Jokubauskas, V. (2014). „Mažuju kariuomeniu“ galia ir paramilitarizmas. Tarpukario Lietuvos atvejis. Klaipeda: Klaipedos universiteto leidykla.

Kazlauskaitè Markelienè, R., Petrauskaitė, A. (2010). ,,Pilietine visuomene ir nacionalinis saugumas: teorine problemos apžvalga. Generolo Jono Žemaičio karo akademija. p. 235-253.

Kodèl verta rinktis tarnybą Lietuvos kariuomenejje. (2018). Prieiga: http:// www.karys.lt/kodel-verta-tapti-savanoriu.html.

Kuzmickas, B. (2018). Tarp kaimynu ir pasaulyje vyksmai ir refleksijos. Vilnius: Versmè.

Laurėnas, V. (2017). Spartëjančios visuomenès politinis režimas. Klaipėda: Klaipedos universiteto leidykla.

Lipinskienė, D. (2012). Motyvuojanti atlygio sistema. Kaunas: Technologija.

Marcinkevičiūtè, L. (2010). Darbuotojų motyvavimo modeliai: teoriniai ir praktiniai aspektai. Kaunas: Akademija.

Maslow, A. H. (2009). Motyvacija ir asmenybe. Vilnius: Apostrofa.

Nikartas, S. (2014). Gyventojų dalyvavimas užtikrinant sauguma bendruomenèse: kriminologinès ir teisinés prielaidos. Vilnius.

Perry, J. L. (1999) Bringing Society In: Toward A Theory of Public Service Motivation. Fifth National Public Management Research Conference, December 3, 1999. Prieiga: http://bush.tamu.edu/pubman/papers/1999/Perry99.pdf

Pocienè, A. (2018). Lietuvos jaunuoliu pritraukimo i nuolatine privalomaja pradinę karo tarnyba galimybès. Lietuvos metiné strateginè apžvalga 2017-2018. T. 16, p. 367-392.

Rodrigues - Goulart, C. F. (2006). Combat motivation. Military review. November - December. Prieiga:https://www.armyupress.army.mil/Portals/7/militaryreview/Archives/English/MilitaryReview_20061231_art016.pdf

Sakalas, A., Šilingienè, V. (2000). Personalo valdymas. Kaunas: Technologija.

Steiger, R., Zwygart, U. (1999). Kariné pedagogika. Vilnius: Generolo Jono Žemaičio Lietuvos karo akademija.

Stumbraitè-Vilkišienè, E. (2013). Piliečiu dalyvavimo ir pasitenkinimo sqveikos konceptualizacija kuriant viešaja paslauga. Daktaro disertacija. Vilnius. Mykolo Romerio universitetas.

Vileikienè, E., Pocienė, A., Aleknevičienè, J. (2015). Motyvacija tarnauti Lietuvos kariuomeneje. Vilnius: Generolo Jono Žemaičio Lietuvos karo akademija.

Vroom, V. H. (1994). Work and Motivation. San Francisco: Jossey-Bass Publishers (Originally published: New York: Wiley, 1964.

Žaptorius, J. (2007). Darbuotojų motyvavimo sistemos kūrimas ir jos teorinè analizè. Filososfija. Sociologija. T. 18. Nr. 4, p. 105-117.

Woodruff, T. D. (2017) Who Should the Military Recruit? The Effects of Institutional, Occupational, and Self-Enhancement Enlistment Motives on Soldier Identification and Behavior. Armed Forces \& Society, Vol. 43 (4). P. 579-607. 


\title{
THE ANALYSIS OF THE MOTIVATION OF SOLDIERS IN THE CONTINUOUS MANDATORY INITIAL MILITARY SERVICE IN THE CONTEXT OF NATIONAL SECURITY
}

\author{
Sgt Spc (OR-5) Gerda Baltutytė \\ MD Jonas Basanavičius Military Medical Service
}

\section{Summary}

Motivated military service in joint development and ensuring the capabilities of country's military security is related to serving soldiers who implement military security strategies and determine qualitative results and efficiency of performed activities. Currently applied factors of motivation in the Lithuanian National Defence System are abstract and non-specific. Furthermore, there are too little researches or studies to justify the (un)successful results of current motivation system. Recognizing the importance of motivation for military service, there is a need to look for theoretical and empirical assurances which, as a starting point, would allow to assess the motivation.

In Lithuania, the Continuous Mandatory Initial Military Service (CMIMS) is based not only on the principle of volunteering but also on coercion (the laws provide for punishment for avoiding CMIMS); therefore, in addition to volunteer soldiers, there are conscript soldiers as well. It should be noted that in comparison with 2015, the number of conscripts in the CMIMS has been increasing. The authorities do not just impose sanctions but also encourage soldiers to engage in joint activities. In order to get them involved, it is necessary to find out their expectations and reasons determining their decision to participate or remain passive in service. The scientific and practical problem is formulated by the following questions: what determines the motivation of soldiers in the CMIMS and how do they evaluate present motivation system used by the Lithuanian Armed Forces?

The results of the local empirical research revealed that the respondents are partly satisfied with current motivation system. Upon assessing the results of the quantitative research and limiting it to the identified institutional and pragmatic motives, it is concluded that the motivation for the CMIMS is based on the institutional type of motivation.

Motivation for military service is particularly influenced by volunteers joining military service. The comparison of the motivation of volunteers and conscripts in the CMIMS in the same appointments revealed a statistically significant difference. The volunteers were more satisfied with their service and had a better opinion of it; they were more motivated to achieve good results, their attitude towards the National Defence Volunteer Forces was more favourable and they considered 
further professional service.

Finally, it was found that the expectations of the CMIMS soldiers were only partially met. Realizing that soldiers will pursue their goals only if they meet their expectations, it is important to look for different ways to motivate military service. When looking for a solution to improve the motivation for military service, it should be noted that attention should be paid to material and non-material promotion of the service, more qualified staff, the quality of exercise, provision and motivation itself.

While analyzing the motivation for military service, there is room for experts and scientists to make suggestions and put forward their recommendations to improve the results of military motivation.

\section{AUTORIAUS LYDRAŠTIS}

Autoriaus vardas, pavardè: Gerda Baltutytè

Mokslo laipsnis ir vardas: socialinių mokslų magistras

Darbo vieta ir pareigos: Dr. Jono Basanavičiaus karo medicinos tarnyba, karo gydytojo padejjèja

Autoriaus mokslinių interesų sritys: karių tarnybos motyvacija, pilietiškumas, gynybos politika.

Telefonas ir el. pašto adresas: 846391 405; gerda.baltutyte@mil.1t

\section{AUTHOR'S COVER LETTER}

Author's name and surname: Gerda Baltutyte

Academic degree and name: Master of Social Sciences

Workplace and position: Military Physician Assistant, MD Jonas Basanavičius Military Medical Service

Author's research interests: military motivation, citizenship, defence policy

Telephone and e-mail address: +370 46391 405; gerda.baltutyte@mil.lt 